Jurnal Ilmu-Ilmu Peternakan 25 (1): 47 - 54

ISSN: 0852-3581

E-ISSN: 9772443D76DD3

CFakultas Peternakan UB, http://jiip.ub.ac.id/

\title{
Analisis kualitas pelayanan terhadap kepuasan konsumen pembeli karkas broiler di Rumah Potong Ayam (RPA) Kelurahan Kampung Mandar, Kabupaten Banyuwangi
}

\author{
Irvan Galantino, Budi Hartono dan Eko Nugroho \\ Fakultas Peternakan Universitas Brawijaya \\ Jl. Veteran Malang 65145 Jawa Timur \\ irvangalantino@gmail.com
}

\begin{abstract}
Research was conducted at the "Kampung Mandar" broiler slaughterhouses located in Riau Street, Kampung Mandar Village, Banyuwangi District. The research aimed to determine (i) the characteristics of carcass buyers, (ii) the level of satisfaction, (iii) the quality of services provided and (iv) factors that affect carcass buyers satisfaction on broiler carcass produced by small scale chicken slaughterhouse. One hundred respondents were selected by accidental sampling method and interviewed using a structured questionnaire. Primary data were obtained from the field (from the customers and chicken slaughterhouses owners) and secondary data were obtained from Central Board Statistics, online media and local government agencies (district office). Data were analyzed using descriptive, factor analysis and multiple regression analysis. The study showed that female traders aged 41-60 years with senior high school education and earned income between IDR. 900.001-1800.000 per month represented broiler carcass buyers. Another findings showed that buyers who considered senior carcass broiler tended to rebuy the product and transferred information to others. The study also found that service quality of broiler slaughterhouse were indicated by "carcass quality assurance and skill sellers", "response to carcass buyers" and "appropriate equipments" and these were able to increase buyers carcass satisfaction.
\end{abstract}

Keywords : poultry, consumer satisfaction, factor analysis.

\section{PENDAHULUAN}

Besarnya permintaan produk pangan memunculkan persaingan antar pelaku usaha. Persaingan usaha terjadi karena jumlah pesaing yang semakin meningkat. Persaingan usaha terjadi pada dua perusahaan atau lebih yang memiliki komoditas produksi yang sama. Persaingan usaha menyebabkan inovasi baru dalam meningkatkan penjualan. Peningkatan konsumsi daging perkapita dan wacana swasembada daging di Indonesia memicu kenaikan permintaan daging di pasar lokal. Konsumen memilih membeli daging ayam karena harganya yang terjangkau. Karkas ayam broiler banyak ditemui di pasar tradisional seluruh wilayah Indonesia. Ayam broiler menjadi komoditi daging konsumsi terbesar di Indonesia karena didukung dengan kemudahan membeli daging broiler di pasaran. Industri Rumah Potong Ayam di bidang peternakan memiliki fungsi dalam pemotongan ayam hidup dan diolah menjadi karkas yang siap dikonsumsi untuk memenuhi ke- 
butuhan protein hewani masyarakat (Singgih dan Karina, 2008). Kemudahan mendapatkan karkas broiler di pasar tradisional menunjukkan banyaknya pelaku usaha yang menyediakan karkas segar untuk konsumen industri maupun rumah tangga

Populasi ayam broiler di Kabupaten Banyuwangi mengalami kenaikan yang signifikan dalam beberapa tahun terakhir. Pada tahun 2010 populasi ayam broiler di Kabupaten Banyuwangi mencapai 475.018 ekor dan mengalami kenaikan dua kali lipat pada tahun 2013 yaitu sebesar 985.142 ekor (Dinas Peternakan Jawa Timur, 2013). Kenaikan jumlah populasi ayam broiler di Kabupaten Banyuwangi menyebabkan jumlah usaha skala rumah tangga dalam sektor penanganan ayam broiler pasca panen meningkat. Usaha skala rumah tangga tersebut diantaranya adalah usaha Rumah Potong Ayam (RPA) yang menyediakan produk karkas segar pasca pemotongan.

Tingginya permintaan karkas broiler di Kabupaten Banyuwangi menimbulkan persaingan antara pengusaha RPA dan memaksa para pelaku usaha meningkatkan pelayanannya. Persaingan kualitas produk dan pelayanan tidak dapat dihindari para pedagang dan memaksa adanya peningkatan kualitas pelayanan yang signifikan. Pedagang perlu memahami perilaku konsumen dan meningkatan kualitas pelayanan Engel et al (2001) menjelaskan bahwa perilaku konsumen adalah tindakan langsung mendapatkan, mengkonsumsi dan menghabiskan produk dan jasa, termasuk juga proses keputusan yang mendahului dan mengikuti tindakan itu. Peningkatan kualitas pelayanan diharapkan dapat meningkatkan kepuasan konsumen dalam membeli karkas broiler. Oleh karena itu penelitian ini bertujuan untuk mengetahui karakteristik konsumen pembeli karkas broiler, tingkat kepuasan konsumen pembeli karkas broiler, kualitas pelayanan yang diberikan dan faktor-faktor kualitas pelayanan yang mempengaruhi kepuasan konsumen pembeli karkas broiler di Rumah Potong Ayam Kelurahan Mandar.

\section{MATERI DAN METODE}

\section{Lokasi dan waktu penelitian}

Penelitian ini dilakukan pada tanggal 28 Januari 2015 hingga 5 Februari 2015 di beberapa RPA yang berada di Kelurahan Kampung Mandar dan beberapa pasar yang berada di Kabupaten Banyuwangi seperti Pasar Induk Banyuwangi, Pasar Blambangan, Pasar Tiga Berlian dan Pasar Pujasera. Pemilihan lokasi penelitian didasarkan pada adanya aktifitas penjualan karkas broiler oleh RPA di keempat pasar tradisional di Banyuwangi dan di lokasi RPA Kelurahan Kampung Mandar. Penelitian dilakukan dengan metode survei yang dipandu kuesioner terstruktur kepada 100 responden yang merupakan konsumen RPA Kampung Mandar yang dipilih secara acak (accidental sampling).

\section{Koleksi data}

Data yang dikumpulkan dalam penelitian ini berupa data primer dan data sekunder. Data primer diperoleh dari wawancara dengan pemilik RPA dan konsumen. Data sekunder dalam penelitian ini adalah data yang diperoleh dari sum-ber kedua yaitu BPS, media online dan lembaga pemerintahan setempat (kantor kelurahan).

\section{Analisis data}

Variabel penelitian antara lain berupa bukti langsung (tangibles), kehandalan (reability), daya tanggap (responsiveness), jaminan (assurance) 
dan empati (empathy). Analisis data dimulai dari pengujian setiap butir pertanyaan dengan uji validitas dan reliabilitas. Pada penelitian ini terdapat 16 sub variabel yang disederhanakan dengan analisis faktor berdasarkan tingkat keeratannya. Hasil analisis faktor kemudian dilanjutkan dengan uji asumsi klasik yang meliputi uji normalitas dan uji multikolinieritas untuk mengetahui apakah data yang dianalisis tersebar secara normal dan tidak terjadi multikolinieritas. Selanjutnya uji korelasi pearson digunakan untuk mengetahui apakah terjadi korelasi antar sub variabel pengamatan. Analisis regresi berganda digunakan untuk mengetahui pengaruh variabel independen terhadap variabel dependen. Alur analisis data dapat dilihat pada Gambar 1.

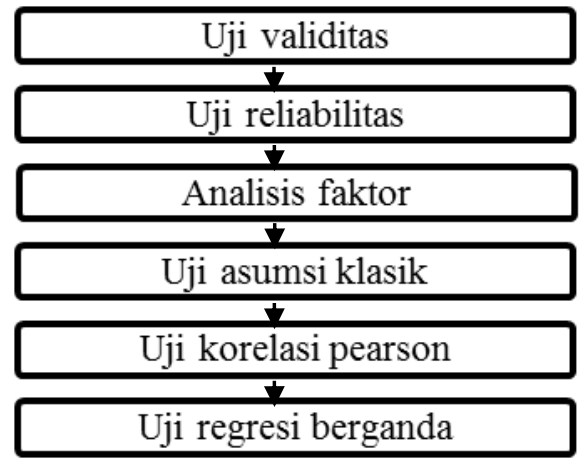

Gambar 1. Alur analisis data

\section{HASIL DAN PEMBAHASAN}

\section{Karakteristik konsumen}

Hasil penelitian menunjukkan perbedaan karakteristik responden yang meliputi jenis kelamin, umur, pendapatan, pekerjaan dan pendidikan seperti yang tersaji pada Tabel 1.

Tabel 1. Karakteristik responden RPA Kampung Mandar

\begin{tabular}{|c|c|c|c|}
\hline No & Karakteristik & Jumlah & Persentase $(\%)$ \\
\hline \multirow[t]{3}{*}{1} & Jenis kelamin : & & \\
\hline & - Laki-laki & 4 & 4 \\
\hline & - Perempuan & 96 & 96 \\
\hline \multirow[t]{6}{*}{2} & Umur (tahun) : & & \\
\hline & - $20-30$ & 8 & 8 \\
\hline & - $31-40$ & 26 & 26 \\
\hline & - $41-50$ & 31 & 31 \\
\hline & - $51-60$ & 31 & 31 \\
\hline & - $>60$ & 4 & 4 \\
\hline \multirow[t]{6}{*}{3} & Pendidikan : & & \\
\hline & - Tidak sekolah & 16 & 16 \\
\hline & - $\mathrm{SD}$ & 29 & 29 \\
\hline & - SMP & 22 & 22 \\
\hline & - SMA & 32 & 32 \\
\hline & - Sarjana & 1 & 1 \\
\hline \multirow[t]{5}{*}{4} & Pekerjaan : & & \\
\hline & - Pedagang & 86 & 86 \\
\hline & - Pegawai Negeri & 2 & 2 \\
\hline & - Tidak Bekerja & 10 & 10 \\
\hline & - Lainnya & 2 & 2 \\
\hline \multirow[t]{7}{*}{5} & Pendapatan (Rupiah) : & & \\
\hline & - Tidak Bekerja & 10 & 10 \\
\hline & - $300.000-900.000$ & 16 & 16 \\
\hline & - $900.001-1800.000$ & 45 & 45 \\
\hline & - $1800.001-2700,000$ & 8 & 8 \\
\hline & - $2700.001-3600,000$ & 5 & 5 \\
\hline & - > 3.600.000 & 16 & 16 \\
\hline
\end{tabular}


Karakteristik konsumen RPA Kampung Mandar menunjukkan bahwa konsumen didominasi oleh $96 \%$ konsumen perempuan pada cakupan usia 41-50 tahun dan 51-60 tahun sebesar $31 \%$. Sebagian besar konsumen RPA Kampung Mandar (32\%) memiliki tingkat pendidikan SMA dengan pekerjaan sebagai pedagang (86\%) dan berpenghasilan Rp.900.001-1.800.000 per bulan $(45 \%)$.

\section{Analisis faktor kualitas pelayanan terhadap kepuasan konsumen}

Hasil analisis faktor menunjukkan bahwa 3 faktor dapat mewakili 16 item awal. Pemberian nama pada faktor yang terbentuk berdasarkan gambaran umum sub variabel didalamnya. Suliyanto (2005) menyatakan bahwa penamaan faktor dalam analisis faktor dapat digunakan nama faktor yang mewakili nama-nama variabel. Hasil analisis faktor tersaji pada Tabel 2.

Tabel 2. Hasil analisis faktor

\begin{tabular}{|c|c|c|c|}
\hline \multirow{2}{*}{ Keterangan } & \multicolumn{3}{|c|}{ Loading factor } \\
\hline & 1 & 2 & 3 \\
\hline \multicolumn{4}{|c|}{ Indeks "jaminan kualitas fisik dan keterampilan penjual" } \\
\hline $\mathrm{X}_{1.1}$ Kualitas fisik karkas & 0,634 & & \\
\hline $\mathrm{X}_{2.1}$ Ketepatan pemotongan & 0,795 & & \\
\hline $\mathrm{X}_{2.2}$ Ketepatan penimbangan & 0,768 & & \\
\hline $\mathrm{X}_{2.3}$ Pemilihan bagian karkas & 0,605 & & \\
\hline $\mathrm{X}_{4.1}$ Kebersihan karkas & 0,596 & & \\
\hline $\mathrm{X}_{4.2}$ Kesegaran karkas & 0,671 & & \\
\hline $\mathrm{X}_{4.3}$ Kehalalan karkas & 0,745 & & \\
\hline $\mathrm{X}_{4.4}$ Kebersihan peralatan & 0,614 & & \\
\hline $\mathrm{X}_{4.5}$ Wadah pengemas & 0,646 & & \\
\hline $\mathrm{X}_{4.6}$ Kesesuaian harga & 0,664 & & \\
\hline \multicolumn{4}{|l|}{ Indeks "respon kepada konsumen" } \\
\hline $\mathrm{X}_{3.1}$ Penerimaan keluhan & & 0,684 & \\
\hline $\mathrm{X}_{3.2}$ Permintaan penukaran & & 0,762 & \\
\hline $\mathrm{X}_{3.3}$ Permintaan maaf pasca keluhan & & 0,841 & \\
\hline $\mathrm{X}_{5.1}$ Prioritas antrian & & 0,601 & \\
\hline $\mathrm{X}_{5.2}$ Respon/sapaan awal & & 0,644 & \\
\hline \multicolumn{4}{|l|}{ Indeks "kelengkapan alat" } \\
\hline $\mathrm{X}_{1.2}$ Kelengkapan peralatan & & & 0,866 \\
\hline$\%$ Varians & 46,54 & 8,02 & 6,24 \\
\hline
\end{tabular}

"Jaminan kualitas fisik dan keterampilan penjual" menunjukkan nilai varian yang paling tinggi diantara 2 faktor lainnya yaitu sebesar $46,54 \%$. Nilai persentase varian menunjukkan bahwa sub variabel yang membentuk "jaminan kualitas fisik dan keterampilan penjual" sangat berpengaruh pada kepuasan konsumen terhadap kualitas pelayanan yang diberikan. Konsumen cenderung merasa puas apabila diberikan jaminan kualitas karkas yang dibeli dan tingkat kehandalan penjual yang tinggi dalam melayani konsumen. Sub variabel pada faktor jaminan kualitas fisik dan keterampilan penjual yang paling dominan mempengaruhi kepuasan konsumen pembeli karkas broiler RPA Kampung Mandar adalah ketepatan pemotongan yang memiliki nilai loading factor 0,795 .

"Respon kepada konsumen" menunjukkan nilai varian sebesar $8,02 \%$ dan mewakili 5 sub variabel kualitas pelayanan. Respon kepada konsumen memberikan kesan penjual dengan pelayanan tanggap dan menghargai konsumen. Penjual dengan pelayanan yang tanggap terbukti lebih disukai oleh konsumen dikarenakan sifat konsumen 
yang selalu ingin diprioritaskan. Sub variabel pada faktor "respon kepada konsumen" yang berpengaruh paling dominan terhadap kepuasan konsumen pembeli karkas RPA Kampung Mandar adalah sub variabel permintaan maaf pasca keluhan yaitu dengan nilai korelasi sebesar 0,841 yang berarti kuat dalam membentuk faktor "respon kepada konsumen"

"Kelengkapan alat" menunjukkan nilai varian sebesar $6,25 \%$ mewakili sub variabel kelengkapan peralatan pendukung. Kelengkapan peralatan pendukung menunjukkan apakah RPA Kelurahan Kampung Mandar menerapkan standar peralatan penjualan minimal saat melayani konsumen. Penjual dengan peralatan yang memadai dapat lebih memuaskan konsumen karena pelayanan yang diberikan lebih cepat dan efisien. Faktor "kelengkapan alat" memiliki nilai korelasi sebesar 0,866 yang berarti kuat dalam membentuk faktor "kelengkapan alat".
Faktor kualitas pelayanan yang mempengaruhi kepuasan konsumen

Model persamaan regresi menunjukkan hubungan antara kepuasan konsumen (Y) pembeli karkas di RPA Kampung Mandar sebagai variabel dependen yang terdiri dari kepuasan dalam membeli karkas broiler $\left(\mathrm{Y}_{1}\right)$, kepuasan terhadap pelayanan dengan keinginan untuk membeli kembali $\left(\mathrm{Y}_{2}\right)$ dan kepuasan terhadap kualitas karkas dengan memberikan informasi kepada orang lain $\left(\mathrm{Y}_{3}\right)$ terhadap variabel independen yang terdiri dari jaminan kualitas fisik dan keterampilan penjual, respon kepada konsumen dan kelengkapan alat. Data variabel dependen dan variabel independen setelah dilakukan analisis faktor kemudian diolah dengan analisis regresi linier berganda melalui program SPSS 16. Rekapitulasi hasil regresi linier berganda dapat dilihat pada Tabel 3.

Tabel 3. Hasil analisis regresi berganda kualitas pelayanan

\begin{tabular}{|c|c|}
\hline Keterangan & Koefisien regresi \\
\hline Konstanta & 10,720 \\
\hline "Jaminan kualitas fisik dan keterampilan penjual" & $0,598 * *$ \\
\hline "Respon kepada konsumen" & $0,417 * *$ \\
\hline "Kelengkapan alat" & $0,141 *$ \\
\hline Umur & $-0,075$ \\
\hline Jenis kelamin & 0,055 \\
\hline Pendidikan & $-0,097$ \\
\hline Pekerjaan & 0,033 \\
\hline Pendapatan & 0,004 \\
\hline \multicolumn{2}{|l|}{$\mathrm{R}$ square $\left(\mathrm{R}^{2}\right)=59,7 \%$} \\
\hline \multicolumn{2}{|l|}{$\mathrm{R}_{\text {adjusted }}=56,1 \%$} \\
\hline \multicolumn{2}{|l|}{$F_{\text {hitung }}=16,826$} \\
\hline \multicolumn{2}{|l|}{$\mathrm{N}=100$} \\
\hline $\begin{aligned} & \underset{c \text { Keterangan : }}{\text { “c }} \\
&{ }_{* *}: \text { hasil analisis faktor } \\
& *: \text { sangat signifikan }(\rho<0,01) \\
& \text { signifikan }(\rho<0,05)\end{aligned}$ & \\
\hline
\end{tabular}


Tabel 3 menunjukkan nilai koefisien determinasi $\left(\mathrm{R}^{2}\right)$ sebesar $59,7 \%$ yang mengindikasikan bahwa kepuasan konsumen pembeli karkas broiler di RPA Kampung Mandar dipengaruhi oleh faktor kualitas pelayanan sebesar 59,7\%. Gujarati (1991) menjelaskan bahwa koefisien determinasi $\left(\mathrm{R}^{2}\right)$ didefinisikan sebagai ukuran kesesuaian dari persamaan regresi dalam varian variabel dependen yang mampu dijelaskan oleh variabel independen. Nilai $R^{2}$ yang rendah mengindikasikan bahwa kemampuan variabel bebas dalam menjelaskan varian variabel terikat sangat terbatas. Nilai $R^{2}$ yang mendekati 1 (100\%) menunjukkan bahwa variabel terikat dipengaruhi seluruhnya oleh variabel bebas. Pengujian model regresi dilakukan untuk melihat tingkat signifikansi variabel bebas terhadap variabel terikat yaitu kepuasan konsumen RPA Kampung Mandar. Uji $\mathrm{F}$ adalah uji secara bersama-sama untuk menguji nilai signifikansi pada 3 faktor hasil ekstraksi faktor yaitu jaminan kualitas fisik dan keterampilan penjual, respon kepada konsumen serta kelengkapan alat berpengaruh pada kepuasan konsumen RPA Kampung Mandar. Rangkuti (2002) menjelaskan bahwa kepuasan konsumen merupakan perbandingan antara tingkat kepentingan dan kinerja atau hasil yang dirasakan. Konsumen membandingkan pelayanan yang mereka dapatkan dibandingkan dengan harapan konsumen.

Uji $\mathrm{F}$ menunjukkan bahwa nilai $F_{\text {hitung }}$ sebesar 16,826 sedangkan nilai $F_{\text {tabel }}$ sebesar 2,04 sehingga dapat disimpulkan bahwa $\mathrm{H}_{1}$ diterima dan $\mathrm{H}_{0}$ ditolak karena $F_{\text {hitung }}>F_{\text {tabel }}$. Kepuasan konsumen secara signifikan dipengaruhi oleh jaminan kualitas fisik dan keterampilan penjual, respon kepada konsumen serta kelengkapan alat. Pengujian secara parsial dilakukan melalui uji t untuk mengetahui apakah masing-masing variabel independen secara individu memiliki pengaruh yang signifikan terhadap kepuasan konsumen pembeli karkas broiler di RPA Kampung Madar. Uji t dilakukan dengan melihat tingkat signifikansi masingmasing variabel bebas (signifikan $<\alpha=$ $0,05)$. Tabel 3 menunjukkan bahwa faktor jaminan kualitas fisik dan keterampilan penjual dan respon kepada konsumen memiliki pengaruh sangat signifikan $(p<0,01)$, sedangkan faktor kelengkapan alat memiliki pengaruh yang signifikan $(p<0,05)$ terhadap kepuasan konsumen RPA Kampung Mandar. Peningkatan kualitas pelayanan yang meliputi jaminan kualitas fisik dan keterampilan penjual, respon kepada konsumen serta kelengkapan alat meningkatkan kepuasan konsumen RPA Kampung Mandar. Data analisis regresi berganda menghasilkan persamaan sebagai berikut:

$$
\begin{aligned}
& Y=10,720+0,598 I_{1}+0,417 I_{2}+0,141 I_{3} \\
& \text { Keterangan : } \\
& \mathrm{Y}=\text { Kepuasan konsumen } \\
& \text { Konstanta }=10,720 \\
& \mathrm{I}_{1} \quad=\text { Jaminan kualitas fisik } \\
& \text { dan keterampilan penjual } \\
& \text { I }{ }_{2}=\text { Respon kepada } \\
& \text { konsumen } \\
& \mathrm{I}_{3}=\text { Kelengkapan alat }
\end{aligned}
$$

Analisis regresi berganda menunjukkan adanya pengaruh positif dari variabel bebas yaitu jaminan kualitas fisik dan keterampilan penjual, respon kepada konsumen serta kelengkapan alat dan kecepatan layanan terhadap kepuasan konsumen pembeli karkas broiler di RPA Kampung Mandar.

\section{KESIMPULAN}

1. Mayoritas konsumen RPA Kampung Mandar adalah perempuan pada cakupan usia 41-60 tahun 
dengan tingkat pendidikan SMA dan bekerja sebagai pedagang yang berpenghasilan antara Rp. 900.0011800.000 per bulan.

2. Konsumen pembeli karkas di RPA Kampung Mandar merasa puas (sesuai harapan) dengan bersedia membeli kembali dan memberikan informasi kepada orang lain saat membeli produk karkas.

3. Kualitas pelayanan yang diberikan RPA Kampung Mandar menunjukkan rata-rata persepsi konsumen mendekati puas (sesuai harapan konsumen) terhadap kualitas pelayanan berupa bukti langsung, daya tanggap dan jaminan serta rata-rata persepsi konsumen puas (sesuai harapan konsumen) terhadap kualitas pelayanan berupa kehandalan dan empati.

4. Kepuasan konsumen pembeli karkas broiler di RPA Kampung Mandar Kabupaten Banyuwangi secara positif dan signifikan dipengaruhi oleh faktor "jaminan kualitas fisik dan keterampilan penjual", "respon kepada konsumen" dan "kelengkapan alat".

\section{UCAPAN TERIMA KASIH}

Penulis menyampaikan terima kasih yang sebesar-besarnya kepada responden dan pemilik RPA Kampung Mandar atas partisipasinya dalam menjawab pertanyaan-pertanyaan yang diajukan. Penelitian ini merupakan bagian dari program Iptek Bagi Masyarakat (IbM) di Kelurahan Kampung Mandar, Kabupaten Banyuwangi.

\section{DAFTAR PUSTAKA}

Abubakar. 2005. Mutu karkas ayam hasil pemotongan tradisional dan penerapan sistem hazard analisis critical Control Point. Jurnal Litbang Pertanian. 22 (1) : 33-39.
Darmawi, H. 2004. Manajemen asuransi. Edisi pertama, cetakan ketiga. PT. Bumi Aksara. Jakarta.

Dinas Peternakan Jawa Timur. 2013. Data statistik populasi ternak Kab/Kota di Jawa Timur. Diakses tanggal 25 November 2014 pada http://www.disnak.jatimprov.go.id /web/layananpublik /datastatistik.

Engel, J. F., Blackwell R. D and Minnard P. 2001. Consumer behavior $9^{\text {th }}$ edition. Ohio. South Western.

Fen, Y. S and Lian, K. M. 2006. Service quality and customer satisfaction: Antecedents of customer's repatronage intentions. Sunway Academic Journal 4.

Gujarati, D. N. 1991. Basic economic. New York. Mc-Graw Hill. Inc.

Huriyati, R. 2005. Bauran pemasaran dan loyalitas konsumen. Alvabeta. Bandung.

Irawan, H. 2007. 10 Prinsip kepuasan pelanggan. PT. Granmedia. Jakarta.

Istianto, J. H. 2011. Analisis pengaruh kualitas layanan terhadap kepuasan pelanggan Rumah Makan Ketty Resto. Jurnal Ekonomi dan Informasi Akuntansi (JENIUS).1 (3) : 88-101.

Kotler, P and Amstrong, G. 2001. Principle of marketing. Prentice Hall, $11^{\text {th }}$ Edition, New York.

Kotler, P. 2005. Manajamen pemasaran, jilid 1 dan 2. PT. Indeks Kelompok Gramedia. Jakarta.

Margaretha, F. 2003. Tinjauan persepsi manajemen terhadap struktur moda perusahaan go public media riset bisnis dan manajemen. Universitas Trisakti. No.3 Hal. 98-115. Jakarta.

Parasuraman, A. 2001. The behaviorial consequenses of service quality. Jurnal of marketing, 60 (2) : 144160. 
Rangkuti. 2002. Analisis SWOT teknik membedah kasus bisnis cetakan kedua. PT. Gramedia Pustaka. Jakarta.

Sarwono, J. 2006. Metode penelitian kuantitatif dan kualitatif. Graha Ilmu Yogyakarta.

Singgih M. L dan Kariana, M. 2008. Peningkatan produktifitas dan kinerja lingkungan dengan pendekatan green productivity pada rumah pemotongan ayam XX purifikasi. Jurnal Teknologi dan Manajemen Lingkungan. Jurusan Teknik Lingkungan FTSP-ITS \& Ikatan Ahli Teknik Penyehatan \& Teknik Lingkungan Indonesia-Jawa Timur. 9 (2) : 7990.

Standar Nasional Indonesia. 2009. Mutu karkas dan daging ayam. SNI 3924: 2009. Badan Standarisasi Nasional.

Suliyanto. 2005. Analisis data dalam aplikasi pemasaran. Ghalia Indonesia. Bogor.
Sunyoto, U. 2004. Pembangunan dan pemberdayaan masyarakat. Pustaka Pelajar. Yogyakarta.

Suryabrata, S. 2000. Pengembangan alat ukur psikologis. Andi Media Publishing. Yogyakarta.

Tjiptono, F. 2004. Pemasaran jasa. Edisi pertama. Banyu Media Publishing. Jakarta.

Tjiptono, F. 2007. Strategi pemasaran. Edisi kedua, Andi Media Publishing. Yogyakarta.

Widjoyo, I. O., Rumambi, L. J dan Kunto, Y. S. 2013. Analisa pengaruh kualitas layanan terhadap kepuasan konsumen pada layanan drive thru McDonald's Basuki Rahmat di Surabaya. Jurnal Manajemen Pemasaran. 1 (1) : 44-57.

Yordanov, D. 2010. Preliminary study of the efficiency of ultrafiltration treatment of poultry slaughter house wastewater. University of Food Technology, Department of Meat and Fish Technology, BG 4002 Plovdiv. Bulgaria. 